\title{
Formal Symbolization Within Spatial Imagination
}

\author{
IMADE BENDI YUDHA \\ Department of Pure Fine Art, Faculty of Fine Art and Design, \\ Indonesia Institute of the Arts, Denpasar, Indonesia
}

\begin{abstract}
The Balinese people are known to be religious. In their daily life activities on the implementation of the religious ritual called panca yadnya (five kinds of sacred rituals), always equipped with the means upakara or offerings are laden offerings with a variety of shapes and images in the form of symbols which are religious magical. The art of offerings is the art of symbols in which concrete and abstract could create artistic as well as symbols of supernatural characters; ten characters, five characters which are applicable and have different functions. And sometimes contradictory according to the needs and intended use. From these observations arose the interpretation of a meaning that, in meeting the needs of human life, basically has two major potential attractions to each other and complementary, i.e. doing structuring/restructuring or order which is oriented on the arrangement of a better life. The deviation/dissension and, even, destruction or chaos that tends to reject the establishment. This is when management is not based on the concept of balance and harmony, it will affect the social fabric of society and is prone to conflict and discord. Hence, the joints destabilize the integrity of nation and state. The concept of the balance contained in the upakara or offering means in comparison to the meaning of life phenomena that occur in society today seems to have been neglected and even abandoned. This can be proven where there has been deviation measures both the nature and the human life, among others, the exploitation of natural resources, discrimination in law and human rights, gender, and abuse of authority in the field of public administration, and will impact the spread of ecological crisis and moral degradation, as well as heighten the level of community poverty. Based on the understanding of the symbols mentioned above, these can be used as an interactive experience as well as a source of inspiration, a creator of images to stimulate natural trigger for the emergence of a sense that if copyright in the form of creative ideas about the values of life. The utterance of his philosophical concepts are abstracted into a work of art by combining with a representative form abstractive application through lines, colors and textures which are varied, and through impasto technique so that they reflect the authenticity of works of art (authenticity of the art work), aesthetic, artistic and reflection of personal value of novelty.
\end{abstract}

Keywords: painting, symbol shape, space, and visual images Runway Creation

The main cornerstone in the creation of works of art was driven by a strong obsession to realize the harmony that starts from the observation of the forms of upakara or Balinese offering means which have provided the imaginative stimuli about the phenomena of life today. Based on the appreciation and reflection done, then it sparks the idea of the essence of distorted societal life action, involving all the actions and behavior that has deviated from the norms of religion, ignoring the values of virtue and truth and tends to harm the interests of others concerning the character of many people's life.

As we know that the phenomenon of life lately seems likely to be coloured by conflicts which happen be- tween one to others. No other cause is due to the nature of human anger in the fulfillment of excessive material needs, especially to the use of natural and human resources by conducting exploitation without realizing humanistic sense. This trend will certainly have an impact on the occurrence of social insecurity, environmental degradation, emergence of various disasters, discrimination against a particular group, forcing the will, and so forth. All these will definitely cause disharmony in the structure of social life.

The phenomenon has become reflections as well as the rationale for lifting the philosophical values of social life associated with harmony, and balance be- 
cause these values have been neglected and even abandoned in organizing the life of today. Therefore, this the reason for reorganizing the life of harmony and balance, the need for self-evaluation as a material reflection to always adhere to the values of morality based on virtue and truth. As stated in the teachings of Hinduism called trikaya parisudha i.e. the three basic types of behaviour which include; good thoughts (manacika), good words (wacika), and good deeds (kayika).

Observation of the forms means, i.e. upakara or offerings as one form of which has a value of high art and philosophy has given an intuitive vibrations that can generate a memory about the values of life as a potential for the emergence of both internal and external drives as outlined into expressive visual language.

The forms are sometimes portrayed to deviate from the real forms, as it is a symbol of abstraction and shapes that exist in nature, such as shape of the gods, giants (bhuta kala), stylization forms of humans, animal images combined with fantasy images resembling totems and plants, such as mountain forms. Then they are given meaning in accordance with the character and shape as a representation of the desired symbols.

Observation and appreciation of the medium containing symbols of upakara or ritual offerings in every activity the Balinese are an interactive experience in social and cultural life which serve as subject matter has given imaginative impetus as well as trigger for the emergence of a sense of art which is reserved for varied and creative visual image sharpening.

In connection with the work of painting that was created, inner experience is transformed into a visual language, as an image to meaningful values. Through distortion and the actualization of nuanced works of art created symbolic abstraction to translate the ideas that come from other forms of infrastructure form of upakara related to Balinese offerings to the social phenomenon that occurs at this time. In the process of creating this painting, the visual elements such as: line, shape, color, texture, space, and organizing elements of which include: composition, proportion, unity, balance, etc., have a vital role as the standard- ization in determining the quality of a work of art. In connection with the discussion about the visual elements and principles of drafting, will be described in detail in each description of the work.

\section{LITERATURE REVIEW}

\section{Understanding Symbols}

According to Coulson, et.al, in Titib, states that: words symbols (in English symbol) means: for something or describing something as well, especially describing something immaterial, abstract, an idea of the quality, the signs of an object, process and others (2001: 63). Then Reede in Titib (2001:63) asserts that: the word symbol comes from the Greek language, "sumballo" which means "I am united with him", "pooling together". What can be united together in the symbol, on the one hand is the form, literal values, and the other party, which guides our lives, understanding or misunderstanding, lack of awareness or consciousness.

So in this sense the symbol is the union together in a symbol, in an effort to achieve awareness or lack of awareness, understanding or misunderstanding, which is done by drawing something immaterial, abstract, an idea, quality, signs of an object. In connection with the work created, the definition can be interpreted as a symbol of the ability of a person / artist in depicting something immaterial, abstract, an idea, quality, signs of an object, process, etc., into a work of art, so bear form new forms of creativity, as representations of ideas or ideals expressed in the paintings.

\section{Form}

In Big Indonesian Dictionary, the noun form which means that connotes a way, whereas in English is called the form. Then, according to Edmund Burke Feldman in the book "Art As Image And Idea” translation of SP. Gustami, (1991:28-29), states as follows: ... The form is "beyond the physical manifestation of a living object, but the field is a "manifestation of an object from the dead. Results of various bentukdapat have linear qualities if attention we are directed at their boundaries, but that contour-contour usually has the effect of making us aware of the form, ie they present the colors silhouette on the field or pagari their space. 
While Djelantik (2001: 18), asserts that: the simplest form is the point. Point itself does not have the size or dimensions. Point itself has no particular meaning. A collection of some points which are placed in certain areas will have any meaning. If the points very close together in a track point will form a line. Some areas together will form a space. Point, line, and space are fundamental forms of art. Based on the above mentioned description, in connection with the creation of this painting, will set forth the form as a physical manifestation of the objects that provide stimulation of ideas. In the visualization of the object will appear as forms of symbolic manifestation of the duality of life that are always complementary. The forms are here in addition to representing the realities of the phenomenon, as well as efforts to seek and find new symbols representative with the ideas to be established.

Overall relationship has to contribute if the copyright sense of the creative in articulating ideas, so it can be used to express the character object imaging using new symbols, while the natural phenomena and social phenomena, imaged through the understanding of the illusions and mind

\section{Imagination}

The term originated from the word image imagination, this is sometimes used to translate the Greek word eidolon, as in Democritus and Epikuros who called frameworks which are sent by objects to our senses in perception. (Good, 2002: 316).

In general terminology is meant by the term imagination is "the power to form a picture (image) or mental concepts are not directly derived from sensation (the Senses)." Imagination is a power, and therefore, the image was directly related to the human beings who have such power. In general, also be understood that the only men that have the power, not the other living things (Tedjoworo, 2001: 21).

Understanding is imagination in the creation of this painting, is an effort to achieve the picture (image) or mental concepts are not directly derived from sensory sensations of a phenomenon that serve as the subject-matter. Images is a spontaneous process which also spontaneously create their own meaning, it strived to get the essence and character of the object through observation, contemplation / contemplation of aesthetic experience has deposits.

\section{Space}

Space is a collection of several pieces that will form a space. Space has three dimensions: length, width and height. Empty space on the original is not contained. Space is entirely filled with the mass of the object is called and if it was thick, its mass becomes heavy. Apart from the three-dimensional, mass has weight. as if there is a fourth dimension (Sumartono, 2005:18). Related to the concept of space is also confirmed by the Indonesian Culture Sumardjo in Archaeology, (2002:85), mentions that: (1) subjective views about the concept of subjective space, without the reality. in other words, place and space is a concept without an objective basis. Because it was only in the form of subjective perception, (2) The view of positivism argue that space and time has no meaning. The reason, both the empirical reality that can not be proved with scientific empirical methods, (3) realistic-extreme view says that space is infinite, eternal, not observed, and a requirement possibility of extension, but not identical with the extension. Space is divided into two, namely the space containing the world, and across the empty space, (4) The view to the four says that space is the real extent berdemensi breadth with length, width, and height. There is no absolute space should therefore be rejected; he differs with the substance of cosmic reality.

Whatever meaning people about space and time seem not just a pointer when the event or something. Space is not just background, location and place twerjadinya events, both of which are a concept that is not illuminated and is not incomprehensible. Efforts to membahasakannya is a game of lila (illusion) which is almost entirely to the discretion dimuarakan (Atmaja, 2003: 5).

Based on the above understanding, the space referred to in this creation is, efforts to form a picture or virtual concepts which are not directly derived from sensory sensations of a phenomenon, whereas in the imagination of space, space is not just background, location or place of occurrence sensory events. Space here was successively virtual concepts unexplained and incomprehensible not significantly, in an effort to show respect is an assumption of an imaginary space of the game of illusion. 
Review the form and symbolic meaning on the means Upakara / offerings Various types of Upakara / offerings in connection with the execution of the ceremony in Bali can be mentioned among them; Pulagembal namely Banten Banten / Upakara used during the ceremonies Manusa Yadnya, especially in commemorating the birthday of someone, whereas form of offerings / Pulagembal larger offerings called skid, used in the course of a ceremony to commemorate the ceremony Yadnya Gods “piodalan” Pura, as a tribute to the ancestors. Bantam / offering this type consists of various types of cakes / sweets that have colorful symbolic meaning of the universe and its contents. Each snacks / cakes include:

Snacks that include the contents of the oceans, plants, flowers, depicting sacred buildings, offerings, described the park, depicts the time, and describes the weapons of the nine gods ruler compass (Son, 1982: 53-54). Sequence of implementation Yadnya Gods, along with offerings such as mentioned above, also accompanied by installing a decorative "lamak" in every shrine / temple, the great centers, as well as on-Penjor Penjor installed, as well as workshop-studio with holes / bear three is where the throne Sanghyang Trisaktii / manifestation Sanghyang Widhi Ida. The most northerly place is the position of Lord Vishnu, usually wearing a bersimbol lamak sea, and disusuni with black cloth. And for positions in the middle of the seat of Lord Shiva (Iswara) uses a bersimbol lamak-Candra Surya and have been prepared with a yellow cloth. While for the most southerly position, the seat of Lord Brahma, who wore besimbol lamak mountain and disusuni with red cloth. Sometimes the seat of Lord Vishnu, the chakras may also use the symbol. So black, yellow, and red symbolizes Sanghyang Tri sakti, as a manifestation of God Almighty (Ginarsa, 1979: 44).

Unlike offerings / Sorohan bebangkit offerings, offerings of this type equipped with the meat, using pork or duck meat, water buffalo, goats or other. Both types of offerings / offerings mentioned above, symbolize two opposite forces that is, the symbol of the positive forces are directed offerings Pulagembal kehadapan Gana god, is the son of Lord Shiva is regarded as the liberator of all odds, rescuers in all its difficulties, the guide of the gods, as well as other things to get a safety, and welfare.
While the negative forces is a symbol of offerings / offerings aimed Bebangkit kehadapan Durga sakti of Lord Shiva in the Bhuta-time control and the forces that are considered unfavorable. The essence of both kinds of offerings / offerings is basically a symbolic meaning in which the positive forces will try to offset the negative forces that will someday pass a balanced (Putra, 1982: 55-56).

According to the book Dewa Ruci, between conversations Wrekodara and Sang Sang Dewa Ruci, explained that; bright light which means the heart is right, which brings people to the nature of the sublime. Black, red and yellow, is the symbol of a barrier or obstacle to human decency in doing good deeds and be a stranglehold that noble intention reserved. Black became a symbol of nature hastiness. Red is the symbol of nature that has desires that are not good, happy to angry and jealous. Yellow is a symbol of nature prevented both actions, and agree to evil deeds. Color white became a symbol of decency, calmness and purity, well pleased with the action (Ginarsa, 1976: 17).

When viewed more information about the existence of the above colors, a color that shows the character that tends to the opposite, because he is a reflection of a condition that dualistic / ambiguous and conflicting with one another, in a natural process towards balance and Living in harmony to achieve a goal for the creation of a harmonious life both physically and spiritual / material and spiritual.

In addition to the colors described above, also known as Datu tri-color which means colors that include three color types, namely: red, white and black. TriDatu is the symbol of Tri Sakti Bhatara namely; red symbol of Brahma, Iswara symbol of white, and black symbol of Vishnu. Three colors were usually carved on the pillars of houses, temples, etc during the ceremony of ordination (pemelapasan). The purpose of the implementation of this ceremony is to keep the occupants, as well as for applying for safety to avoid the interference of demons.

Namely coloring materials used; color red from the blood of slaughtered animals, the white color of whiting, and the black color of charcoal. Datu tri-color is also used on the thread which is now called tri-Datu thread (tetebus). This yarn is widely used by Hindus 
in Bali in doing Manusa Yadnya ceremony and also at the ceremony "abhaya kala" (biah-kaon) in the feast of red Galungan.Warna strapped on the wrist, black ankle strapped on, and white color disuntingkan of the ears, good for calming the mind in order not to be tempted by the influence of non-no. There are also the three-three tri-Datu threads that digelangkan on the right wrist and the other is spread on the fontanel which all were delivered with a prayer that he meant so strong, firm and long life.

Based on the above understanding of the values embodied in the concept of threads "tri-Datu", is related to energy that includes nature, red (fire) as the power of Brahma, black (water) as the power of Vishnu, and White (wind / air) as Iswara strength, capable of transferring power and permeated throughout human life, that could form the character and nature of every human being, in accordance with their own karma. This is a reflection of the nature of good / positive or negative that is within human beings, to do instropeksi themselves against acts of thought patterns and pattern matching for teciptanya life and balanced, based on mutual respect, mutual sharpening, love and education.

Similarly, in the execution ceremony Yadnya Bhuta, which makes caru (sacrificial animal) which contain "gayah". Material from gayah consists of meat animals and plants, and placed spikes to the base of a coconut or a head of a slaughtered animal, then on top dikerubuni with jejaringan (a thin membrane in the animal's stomach). animal meats such as satay stabbed shaped to resemble a weapon is a weapon of the Gods Nawasanga Gods exist in the eyes of nine over the direction of the wind. Gayah has meaning, stating spontaneous outburst of human conscience (in this case the owner of the work), to harmonize the relationship between the sacred power of Bhuana Agung Alit Bhuana sacred power that is in essence to balance. This becomes very important, where there is a balance, so there the place of tranquility, the balance between the Atma (soul) with Paramatma (God Almighty) is the essence of the purpose of Hindu Dharma (Ginarsa, 1976: 20-21).

Based on experience of observing these things, has spawned an aesthetic sense and imagination for the emergence of creative ideas, to dijelmakan to form in the paintings. Observing the phenomenon that occurs in this context, where social life has now be- come a potential to be a land dispute and conflict arena, in realizing the ideals of political interests and power. It seems likely to sacrifice the interests of the broader integrity of the joints of nation and state, because the establishment has neglected to break even, by distortion of the values / codes of conduct in social life, and out of the principles of balance and can ultimately lead to Chaos is everywhere.

\section{PROCESS OF CREATION}

\section{Creative Process}

In the process of creating art by using a semiotic approach, because the data that will study in the creation of this form of signs. While the methods of hermeneutics and symbolic approach is used because the data that will study the form of interpretation, and the form of symbols. While the creation of methods used in this creation is to use Hawkins's theory, because the method can be used as signposts that guide and direct the mindset and follow a more systematic pattern. This will further simplify the steps in engineering applications, as well as in implementing the ideas and the stages of creation, so the problems that this can be done in the creation of clearly described and elaborated in an optimal fashion.

\section{Stages of Creation}

\section{Exploration}

In the early stages of the process of creating this painting, that is to make observations and pencermatan on the forms and symbolic values in the forms Upakara / Balinese offerings, which it contains the spiritual teachings of occultism that dualistic, to be used as a source of inspiration. Observation of such symbols is done by observing directly to places like the Temple solemnization, to people's homes / people of Bali, which performs a religious ceremony. In addition, in this study also conducted an assessment of reference books that contain a variety of information theory and the pictures of the kinds of Upakara / offerings that have symbolic value stored in the magical ancient museums, such as museums Gedong Kertya in Singaraja , and the Museum of Bali.

Through observation and selection of exploration results obtained from the personal experiences of the past, has stirred the imagination of space, so there is an obsessive anxieties, to present imaginative forms 
a representative with the concept of creation, both in text and context. More important things done in this phase are: conducting interviews with resource persons who are considered competent in their fields such as; experts offerings / offerings, stakeholders (people who usually are often led in the ceremonies in Balinese society), Sulinggih (pastor, pedanda or srimpu), and traditional Balinese writers. This becomes important as the study materials to obtain primary data that can support the accuracy of the data to be analyzed, prepared as a reporting material.

\section{Experimentation}

In the conduct of experimentation, there are five components of creativity is the production of valuable new ideas offered by Sternberg and Lubant in Myers, (2004: 102-104), which includes: the first component is a skill. More and more ideas and images that we get through the learning that accumulates, the more we have many opportunities to combine the building blocks of creative ways. The second component is imaginative thinking skills. In moments of creativity, we see things with new ways, to recognize the various patterns and create various relationships. Having mastered the basic elements-the elements of a problem, we redefine or explore a new way.

The third component is a personality who loves adventure. Able to bear the personal creative ambiguity (ambiguity) and the risk, persistent in overcoming various obstacles, and trying to find new experiences. The fourth component is the intrinsic motivation. Society will become more creative when they feel motivated primarily by interest, pleasure, satisfaction and challenge of the work itself rather than by the various pressures from outside. The fifth component is a creative environment. New ideas and values are often articulated, supported and refined by a number of relationships.

The five ideas above have provided encouragement and mental stimulation to shed themselves of all anxiety by conducting experimentation to make setsacreative sketches and improvisation of materials of paper, china ink and pencil, so that past experiences are recorded in the memory, imagination is stimulated to explore the potential , so they can give birth to the motives and ideas are brilliant. These sketches were selected and then a few selected to be recon- structed, and elaborated to become a design that will be realized and used as a reference in the creation of works of art. Sketches chosen in this case, does not necessarily transferred directly into the work to be realized, but with careful consideration regarding the idea, aesthetic, and artistic, sometimes even abandoned altogether, because it was considered not representative of ideas that you want.

\section{Formation}

Phase formation in the creation is done through the transformation of selected sketches, and then reconstructed and elaborated on the canvas. In this case, sometimes there is a significant change in thinking to the design of the previous sketch, because in the creative process must involve intuition to make breakthroughs on various aspects. Aspects referred to are things pertaining to the processing composition, coloring, texture application, the division of the composition of the field or space so that the needs of aesthetic expression, and artistic, which is part of the idea can be elaborated in an optimal fashion.

In addition to the steps above applications, the formation is also performed by using a brush, through a stroke of colors and varied improvisation on canvas which has ditekstur evenly. By applying and developing the strength of denture-line elements as well as take advantage of the ability of plaque staining technique (opaque), overlapping (Impasto), the shapes or figures that appear capable of presenting thematic associations and support the achievement of the representation of ideas.

The emergence of image shape / of certain figures and motifs on the stages of this formation, can also be achieved using textured materials such as modeling paste is rolled or etched using a palette knife with an optimal thickness in accordance with the form to be achieved. Texture was then scratched with a sharp stem of the brush and it will appear the traces of a line or an artistic scratches and scrapes when the trace lines are colored dark. Through the coloring process like this can provide a variety of alternative shapes and atmosphere that can be developed primarily on the achievement of shapes and colors of an imaginary, solid, and varied, to represent the symbolic values as desired. The tips of this kind conducted so that these effects can support the aesthetic and artistic quality in his work, able to evoke 
an impression of depth, magical impression, from the forms and symbols that are displayed. The paint material used is acrylic paint brands Winsor Galleria, because this kind of color can provide easiness which means, to achieve effectiveness and efficiency, as well as having a strong character and make it easier to close the achievement because the rapid dry form.

Applications colors through technical excellence that is owned, as well as accuracy in penataanya, able to reach plaque technique (opaque) or the desired Impasto technique ferfect, as an effort to find keunian-uniqueness forms for the attainment of selfidentity and orijinalitas / authenticity of works of art (authenticity of the art work). In realizing an idea in its formative stages, there are some things to be one part of perioritas to be aware of a set of tools such as tools and materials to support the achievement of a form that is poured into the paintings. The materials used are: canvas, acrylic paint, textured materials such as modeling paste, color mixing water as well as a matt varnish coating / protective works are not easily subject to mold and dust. While the tools used to support engineering applications are: pallet knife, brush with a variety of sizes, appliance rollers, and plate glass as a place to mix paint. After the materials and tools available, then the stages of formation can be continued to intensely to achieve diingikan ideas.

\section{RESULTS AND DISCUSSION}

Some of the major tasks as an artist is able to put ideas / ideas to the art form in which the values symbolic terselipkan full of meaning, as a reflection of the level of weight form (text) and content (context) of artwork created . Embodiment of paintings done by some process / stages that involve pemiikiran and creative actions, including anticipatory steps in the face of obstacles and risks. This becomes very important, because it will determine the direction of travel in search berkeseniannya identity in order to gain public legitimacy of the existence of self through their works.

In addition, if the issues above have been achieved, the next task for an artist is that he should be able to articulate and describe the work of creation through verbal language, as well as appearing in the broader social field so that his works can be fully appreciated by society. In order for the articulation work that is created can be fully understood in terms of both text and context, and to facilitate communication between the occurrence of contact with the artwork intellectuals, among artists with appreciators, below will be described in details on the elaboration of paintings created as follows.

A cat with its movements when passing in front of our eyes in the early morning while foraging, sitting while asleep, or playing with children or with friends, will very cute because the animal is funny, innocent and docile, as if he/she just receive all the reality faced in his life. But this reality will be changed when (s)he has to fight for his life in order to show his/her existence in the evening, because at night (s)he must exert all his strength in risking his/her life, and if certain conditions at a friend's house (s)he could be the opponent for a bite to eat.

Inspired from the above phenomena it can be interpreted as meaning that in pursuing a multi-dimensional life, we must intelligently react to it, always vigilant like the cat that night because there will always be someone else lurking around our behavior, and may endanger one's life in an attempt to achieve the ideals. From the meaning described above, and then visualized through the shape of a cat with red stripes stand upright body position, eyes wide as if he were looking at something, and sharp teeth, ready to pounce on his enemies who will disrupt and attack.

Expressions of the form shown by this work, intended as a symbol of manhood, ready to speculate, never give up and always be introspective in order to achieve a goal, because in life we make progress not only opportunities that are lurking there, but we are also always under surveillance by the people around in order to compete even to thwart. The colors in the visual work are a combination of an integrated, harmonious between dim and bright colours, but are expected to give the impression of an imaginary atmosphere and the aesthetic visual appearance and harmony.

The Balinese traditional art form of dance performances in the sacred barong Brutuk Trunyan is a primitive dance that symbolizes the meeting of two major energy power between the power of mother (Mother Earth) with the strength of space (akasa), 
which relies on the fertility of the worlds so as to be able to provide livelihood for the people. When observed closely the real situation that happens to the adult nature of this situation, in fact it will be very different from the fairy tales or myths which they believe to be able to provide welfare for life through the ritual sacrifice they do. This phenomenon occurs because the natural look was not friendly with humans, because of modern human behaviour is too nosy and heinous in the nature of beauty and sustainability. It can be proven that many industrial wastes such as plastic, cloth scraps of nylon, chemical substances from the garment industry pollute water source tributaries around them.

The major problem faced by almost all residents in parts of the world today is making the creators of the increasingly called upon to express themselves through works of art, as part of a form of participation or awareness that is expected to give contributions in an effort to participate as well as preserving the natural environment. This is manifested in the visualization work of painting, through the transformation of forms diverse from Brutuk Barong with various expressions and variations of primary colors; secondly, and the colors are arranged in such a way imaginary to represent the unique forms and symbols in order represent the ideas expressed.

Various forms and expressions of Barong Brutuk with feathers made of fabric-colorful patchwork symbolizes the source of life that exists in nature which has been sick since tarnished by the various manufacturers of industrial waste and sewage dumped so haphazardly. Even so polluting the environment and nature, damaging the source of human life. In the background appears natural portraits on display and indescribable swamp full of gravels as a natural mirror tangled sad because it is damaged due to human maltreatments that only exploit profit from nature without caring its sustainability.

\section{CONCLUSION}

Symbolization forms in spatial arts-inspired images of the forms upakara facilities or offerings in Bali is the symbol of human attitudes and behaviours of conflicting and tends to be distorted anarchist which exists in the social life as a reflection of two great powers, among which is constructively distorted and is always animate life. As for this, the Balinese believe that two elements have of great strength which are always there in this life; to be mutually attracted and complementary to each other.

The dualistic conception of the life of the people of Bali, which is covered and has been described in other forms of upakara facilities or offerings includes a variety of things, including the lives of the two worlds both real and unreal, material and spiritual. Such philosophical insights to this is an important guide containing the essential and fundamental, and indispensable for the realization of the socio-cultural life of the order of the Balinese community- oriented principles to life, birth, and attainment of inner balance, to the creation of the life jagadhita.

The formal symbolization as a basic concept of the creation of this painting is the result of the study and understanding of the values that is inspired by Bali's form of upakara facilities Bali which have provided spatial stimuli evoking images of intuition and creation in working out the art. This is done as the optimal effort in discovering how the authenticity of styles of art (authenticity of the art work) are created. In connection to the creation of these abstractions to be used as a text which is expected to address the contextual and to bridge any problematic issues that continue to grow and is currently facing the world community are through the realization of brilliant ideas and creative works of art into painting.

Though the expressions of creativity and sense poured through the visual language of painting, the result is part of a text which is then articulated in details concerning problems that occur during the processes of contextualization. Visual manifestation of the work is expressed through selection, reconstruction, elaboration, sometimes even deconstruction by applying various techniques and arrangements of elements of art, such line, color, shape, texture, area or space, and more emphasis on intensity to achieve quality 'of form and content" of work of art is certainly created. The elements and visual elements above are organized in such a way, and then arranged in a dynamic and intact composition without neglecting the elements of aesthetic, artistic achievement and harmony, paintings are created to bear forms with new meaning; Hence, through creative ideas individual work of art that is symbolic is created. 


\section{REFERENCES}

Atmaja, Jiwa. (2003), Perempatan Agung: Menguak Konsepsi Palemahan Ruang dan Waktu Masyarakat Bali, CV. Bali Media Adhikarsa, Denpasar, Bali.

Djelantik, A.A.M. (1990), Pengantar Ilmu Estetika: Estetika Instrumental, Sekolah Tinggi Seni Indonesia Denpasar, Denpasar.

Hadi, Sumandyo Y. (2003). Mencipta Lewat Tari, Mantili, Yogyakarta.

Driyarkara. (1980), Driyarkara Tentang Kebudayaan, Yayasan Kanisius, Yogyakarta.

Feldman, Edmund Burke. (1967), Art as Image and Idea, Prentice-hall, Inc. Englewood Cliffs, New Jersey, atau "Seni Sebagai Ujud dan Gagasan" terjemahan SP. Gustami. (1991), ISI Yogyakarta, Yogyakarta.

Ginarsa. (1979), Gambar Lambang, CV. Sumber Mas, Denpasar.

Hartoko, Dick. (1984), Manusia dan Seni, Kanisius, Yogyakarta.

Hooykaas,C. (1980), Drawings of Balinese Sorcery, Institut of Religius Iconography State University Groningen Leiden E.J. Brill.

Kartika, Sony Dharsono. (2004), Seni Rupa Modern, Rekayasa Sains, Bandung.

Nars, Seyyed Hossein. (1984), Antara Tuhan, Manusia dan Alam, IRCiSoD, Yogyakarta.

Read, Herbert. (1959), The Meaning of Art atau Seni Arti dan Problematiknya. terjemahan, Soedarso Sp., (2000), duta Wacana University Press, Yogyakarta.

Sachari, Agus. (2000), "Riset Bidang Disain dan Kesenirupaan” dalam Refleksi Seni Rupa Indonesia. Balai Pustaka, Jakarta.
Sidik, Fadjar dan Aming Prayitno. (1979), Disain Elementer, STSRI ASRI, Yogyakarta.

Soedarsono RM. (2001), Metodologi Seni Pertunjukan dan Seni Rupa, Masyarakat Seni Pertunjukan Indonesia, Bandung.

Soedarso SP. (1990), Tinjauan Seni: Sebuah Pengantar Untuk Apresiasi Seni, Saku Dayar Sana, Yogyakarta.

Sudharta, Tjok Rai. (2001), Upadesa: Tentang Ajaran-ajaran Agama Hindu, PARAMITA Surabaya, Surabaya.

Sumardjo, Jakob. (2000a), Filsafat Seni, ITB, Bandung.

Sumartono. (April 1992), “Orisinalitas Karya Seni Rupa dan Pengakuan Intenasional” dalam SENI, Jurnal Pengetahuan dan Penciptaan Seni. II/02. BP ISI, Yogyakarta.

Sutrisno, Mudji SJ. (2004), Ide-Ide Pencerahan, Obor (Anggota IKAPI), Jakarta.

Sunarya, I Ketut. (2004), “Konsep Rwa Bhineda Seni Kriya di Bali: Studi Kasus Ukiran Kayu Karya I Ketut Tulak”, Tesis, Program Pascasarjana Institut Seni Indonesia Yogyakarta, Yogyakarta.

Sutrisno, Mudji SJ. (2004), Ide-Ide Pencerahan, Obor (Anggota IKAPI), Yogyakarta.

Tedjoworo. (2001), Imaji dan Imajinasi: Suatu Telaah Filsafat Postmodern, Kanisius, Yogyakarta.

Titib, I Made. (2001), Teologi \& Simbol-Simbol dalam Agama Hindu, Badan Litbang Parisada Hindu Dharma Indonesia Pusat, PARAMITA Surabaya, Surabaya.

Tucker, Mary Evelyn \& John A. Grim. (2003), Agama, Filsafat, \& Lingkungan Hidup, Kanisius, Yogyakarta.

Wisetrotomo, Suwarna. (1998), Melacak Garis Waktu dan Peristiwa, Departemen Pendidikan dan Kebudayaan, Jakarta. 